\title{
TINNITUS AUDIOGRAM
}

\author{
$\mathrm{By}$ \\ T. NAGAHAMA \\ From the Department of Oto-Rhino-Laryngology, Nagasaki University \\ Medical School (Chief: Prof. T. Goto)
}

The author masked tinnitus by pure tone and established fous types of tinnitus aud ograms.

The tinnitus audiogram which recorded the relationship between the threshold curva of air conduction hearing and the masking curve of tinnitus showed the characteristics of tinnitus most distinctly.

Curve $A$ represents the threshold curve of air conduction and curve $B$, the masking curve of tinnitus.

Between these types of tinnitus audiogram and the types of tinnitus classified by author according to the audiography, there were following relationships.

1) Parallel-horizontal form (Curve $A$ and curve $B$ run almost parallel with zero level of normal hearing) was found frequently in conductive tinnitus.

2) Parallel form (Curve $A$ and curve $B$ run almost parallel, but decline in the high tone zone) was seen frequently in perceptive tinnitus.

3) High-tone convergence form (Curve $A$ and curve $B$ converge in the high tone zone) was seen ferquently in non-deafness tinnitus.

4) High-tone divergence form (Curve A and curve B diverge in the zone of high tone) was seen frequently in perceptive tinnitus.

5) Low-tone convergence form (Curve $A$ and curve $B$ converge in the low tone zone) was seen frequently in non-deafness tinnitus and conductive tinnitus.

6) Irregular form(No definite relationship between curve A and curve B) was seen frequently in perceptive tinnitus.

\section{Tinnitus Audiogram に 就 $\tau$

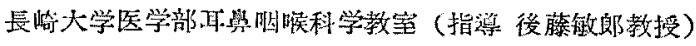 \\ 盺手永浜武产}

耳鳴研究の最大の除路は耳鳴を他覚的に記録できない ことでする。この除路を克服するために純音を用いて耳 鳴を隐蔽し，所謂 tinnitus audiogram を描き，これに よつて耳鳴の性質（大いざ，周波数等）を求め，耳鳴の 䛦断，耳鳴成因の追求に利用する方法が考穴られてき た。例完ば大和田氏等 の原疾患を求めようと試みたし，水落氏2）は耳鳴遮蔽
現象を利用して耳鳴を分類する方法を報告した，著者引 もさきに耳鳴遮敬曲線を耳鳴の治療効果判定に用いた が，本篇では tinnitus audiogram の種々な表現方法に 試て研究した成績を報告する。

\section{耳鳴遮蔽検査法}

症例は持続性耳鳴を有する患者で，防音窒内で耳鳴を はつきり自覚し得るるのを選んだ，患側は一側性，両側 
性のいかんを閣わすに行つた。

先つ耳鳴を著者の方法によつて聴力像に従つて無難聴 性耳鳴, 伝音性耳鳴, 混合性耳鳴, 感音性耳鳴（迷路性 耳鳴あるいは后迷路性耳鳴に細分される例もある）に分 類した。

被検者に耳鳴遮酸検查法の力法並びにその賞義を充分 に納得させた上，先ず audiometer の最低周波数の純 音を次第に大きくし，これによつて耳鳴が聴えなくなつ た値を求め，これを各周波数について行い，正常者最小 可聴䦪值を基準にした audiogram を作り，これを耳鳴 遮敕レベルとした。この測定には疲労むるいは順応の観 点から ascending method のみを用い，1 1つの周波数 に就ては1〜2 回の測定に止め，反復繰返すことは避け た.

\section{tinnitus audiogram の作リ方}

耳鴊の遮蔽に要した純音の強さを各周 波数に就て求めこれを逜続して一つの曲 楾を作ることができたが，この曲線を臨 床的覞祭に便なるように次のようなグ フの現し方を考えてみた。本蜆察に用い た症例は150耳である。

I) 耳鳴遮蔽曲線と気恶曲線つ関係加 ら見た tinnitus audiogram

耳鳴遮蔽曲線は被検者の最小可聴間值 を゙にした際の耳鳴の audiogram とさ れている.この鵈遮䔩曲線と気導曲線 との関保を次のようなV型に分つた，第 1 区は各型の典型的な例であるが，中央 の○レベルは耳鳴遮蔽曲楾に対しては被 検者の最小可聴閾值であり，気導曲線に 対しては正常者の最小可聴間値を示した ものである。

I 型平行水平型（水平型）…耷鳴遮蔽 曲線，気導曲線共に○レベルに効して略 水平に走る型.

II 型平行高音下降型（平行型）…気導 曲線忙高音斜降型あるいは急型型を示 し，而も耳鳴遮蔽曲線もこれに平行する 型.

回型（高音取歛型）…気頱曲線は0レ ベルにほよ゙水平に走るのに対し耳鳴遮薢 曲線住高音に移るに従つて下降するので 高音域にて両曲線が接近する型。
IV 型 (高音分離型) …耳鳴遮䃌曲線は水平型であるが 気導曲線は高音斜降型を旺するので高音域では両曲線が 分離する型.

V型（低音収歛型）…気導曲線は水平型であるが，耳 鳴遮蔽曲線は四型（高音収歛型）と反対に低音程下降し ているので両曲線が低音域にて接近する型。

V型（不定型）‥耳耳鳴遮蔽曲線と気筫曲線と.0＼cjkstart間にI 〜V型の如き著明な関䋆が見られないるの.

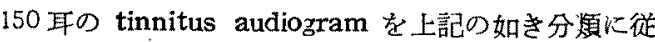
つて各型に分计て観祭した（第1表）.

㕛各耳鳴毎に各型つ占める百分率を示した（第2図）.

耳鳴全体でタるとI型 (水平型) が最も多く42耳 (28 \%)，II 型 (平行型) が 39 耳 $(26 \%)$ でこれに次ぎ，以 下IV型（高音分離型） 24 耳 (16.0\%)，V型（低音取劒

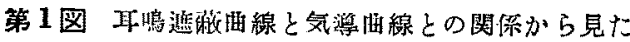
tinnitus audiogram
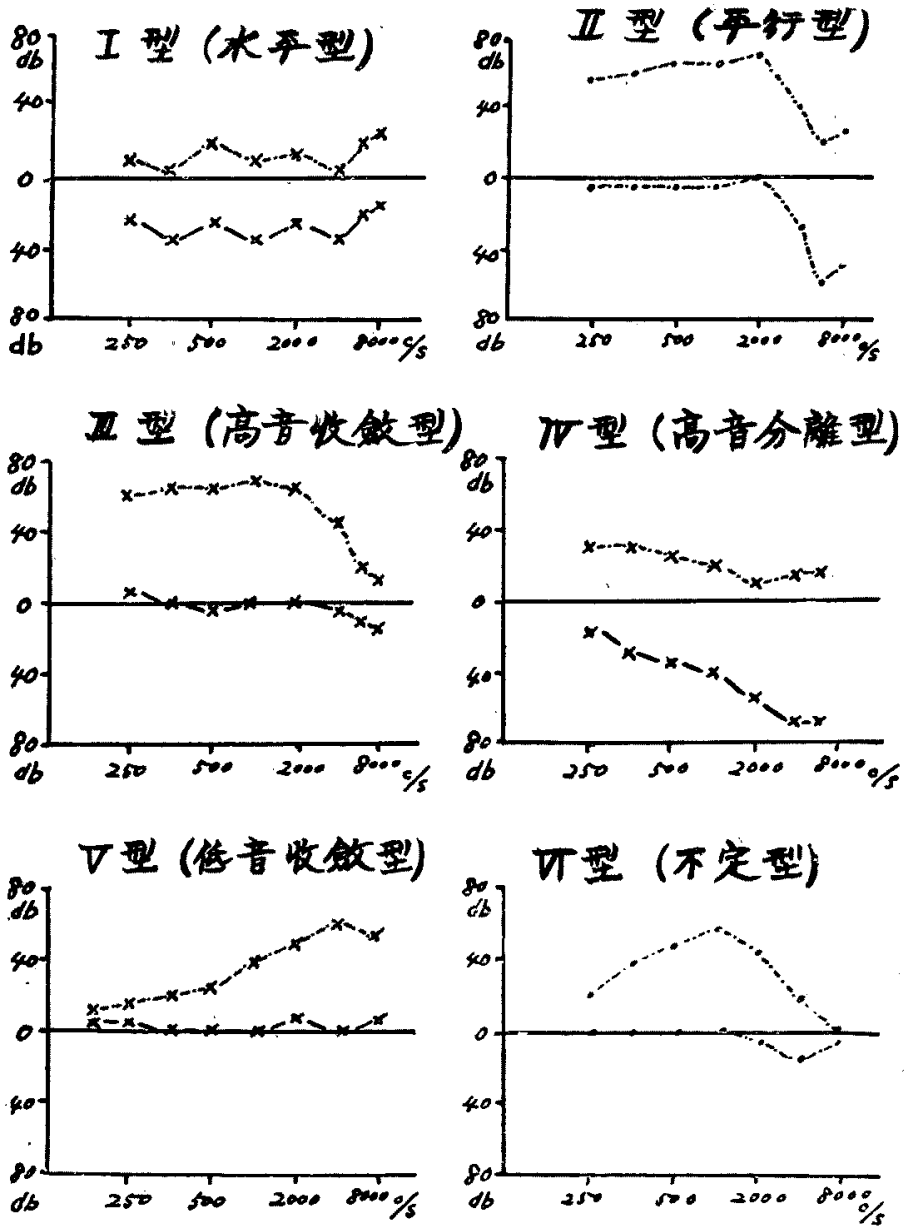


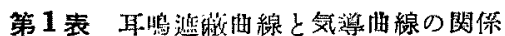

\begin{tabular}{|c|c|c|c|c|c|c|c|}
\hline & 型 & 型 & 开 & 型 & 型 & 者 & \\
\hline 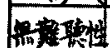 & 7 & 0 & 6 & 0 & 4 & 0 & 17 \\
\hline 音性 & 10 & 0 & 1 & 0 & 3 & 1 & 15 \\
\hline 栓性 & 12 & 5 & 0 & 4 & 1 & 2 & 24 \\
\hline 威音性 & 13 & 34 & 4 & 20 & 8 & 14 & 84 \\
\hline $\mathrm{x}$ & 5 & 13 & 0 & 8 & 1 & 3 & 30 \\
\hline & 1 & 5 & 3 & 3 & 1 & 4 & 17 \\
\hline to & 42 & 39 & 11 & 24 & & 19 & 150 \\
\hline
\end{tabular}

最多であつた。

I型（水平型）には伝音性耳鳴，無難聴性耳鳴が多く 感音性耳鳴は少かつた。然るに型（平行型）には無難 聴性耳鳴，伀音性耳鳴は見られずに感音性耳鳴が多かつ

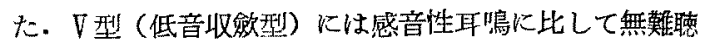
性耳鳴，伝音性耳鳴が多く，III型（高音収歛型）では特 に無難聴性耳偏が多かつた。これに対しV型（低音収敛 型) とII型 (平行型) では無難聴性耳鳴, 低音性耳鳴は 見られず感音性耳鳴が最も多かつた。

無難聴性耳鳴は感音性耳鳴よりも伝音性耳鳴に関係が 梁い性質を持つているように㒻えた。

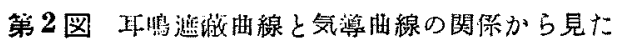
tinnitus audiogram

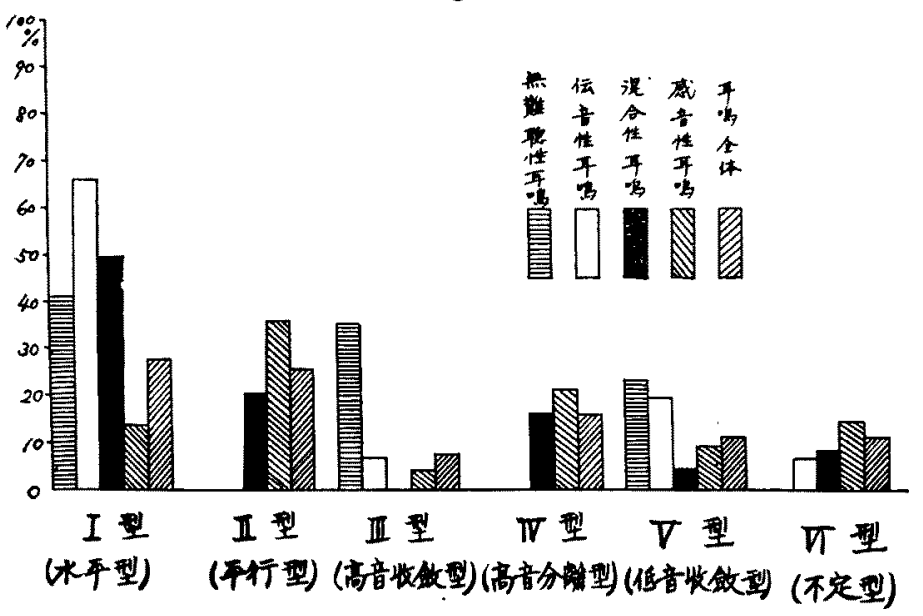

II）耳鳴遮蔽レデルから見た tinnitus audiogram

耳鳴遮桃に要した純音の大きざをと 耳鳴遮蔽レベルを表すことにした。従つ てこの際の゚レベルは健耳の最小可聴 闒值である。この耳嗎遮蔽レデルから tinnitus audiogram 分類することを 試みた。

第 1 型（水平型）…正常者の0レベル に対して耳鳴遮敕レペルはほよ゙水平に走 る型.

第2 型 (高音上犁型) …高音に移るに 従つて耳鳴遮蔽レデルが低くなるもの。 即ち小さい音で遮敬できる例.

第3 型（高音下降型）…第 2 型と反対 に高意による程耳鳴遮蔽レベルが大とな

型) 及びVI型 (不定型) の各 17 耳 $(11.3 \%$ )，四型(高 音収歛型) 11 耳 (7.4\%) の順であつた。無難聴性耳鳴 17 耳ではＩ型（水平型）７耳 $(41.2 \%$ )，血型（高音仪 歛型) 6 耳 $(35.3 \%) ， \nabla$ 型 (低音收歛型) 4 耳 $(23.5 \%)$ で，I型 (平行型)，IV型（高音分離型），VI型（不定 型)はなかつた：伝音性耳鳴 15 耳ではI型（水平型） が 10 耳で $2 / 3$ を占め，V型（低音収歛型） 3 耳 $(20 \%)$ ， III 型 (高音收歛型)，V型（不定型）各1耳（11,3\%) で，I型 (平行型)，IV型(商音分離型) は認められな からた。感音性耳鳴ではI型(平行型) 34 平 (36.2\%), $V$ 型（低音收敛型） 20 耳 $(21.3 \%$ ), V型（不定型）14 耳 $(14.9 \%)$ ，I型（水平型）13耳 $(13.8 \%$ ), V型（低 音収铞型) 9 耳 $(9.6 \%)$ ，而型（高音分離型） 4 耳 (4.2\%) でいずれの型にもみられた：迷路性耳鳴30耳ではI型 (平行型) が13耳 $(43.3 \%$ ) で最も多かつたが，后迷路 性耳鳴 17 耳でも同様 II型（平行型）が 5 耳 (29.5\%) で
る型.

第 4 型（四型）…中音域で耳鳴遮薢レペルが大となる छの.

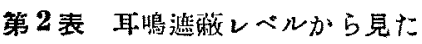
tinnitus audiogram

\begin{tabular}{|c|c|c|c|c|c|c|}
\hline & 81 & 米2型 & | & $\geqslant 4$ & 75 & It \\
\hline 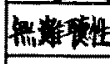 & 5 & 6 & 4 & 2 & 0 & 17 \\
\hline 伝音惟 & 7 & 2 & 2 & 0 & 4 & 15 \\
\hline 湜合性 & 7 & 0 & 11 & 0 & 6 & \\
\hline 感音性 & 34 & 6 & 40 & 6 & 8 & \\
\hline 怔 & 13 & 1 & 13 & 0 & 3 & 30 \\
\hline & 2 & 3 & 9 & 4 & 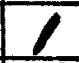 & 11 \\
\hline (F) & 53 & 14 & 57 & 8 & 18 & 162 \\
\hline
\end{tabular}




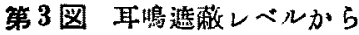
見 audiogram
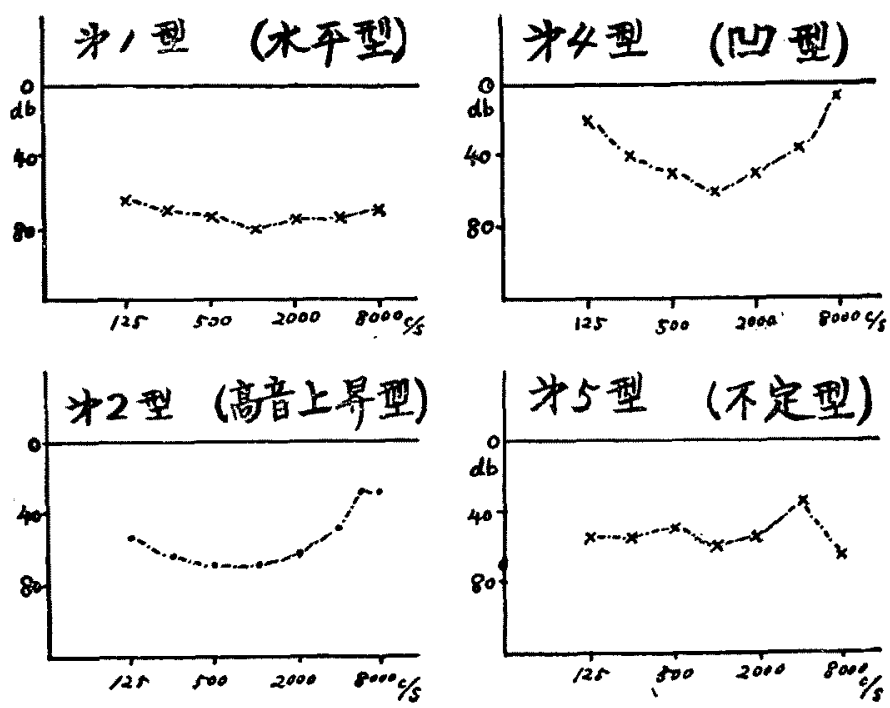

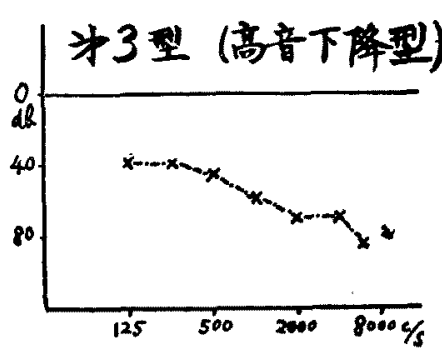

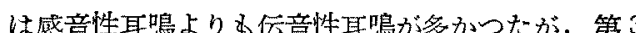
型（高音下降琶）では感音性耳鳴が伝音性耳哿より 6多かつた，第2型（高音上型型）では14 耳中 6 耳 (42.9\%) を無難聴性耳鳴が占め，又第4 型(叫

第 3 表 耳㖵㵂蔽曲線の淈

\begin{tabular}{|c|c|c|c|c|c|c|c|c|}
\hline & 任予 & $\begin{array}{l}\text { 水 } \\
\text { 年 } \\
\text { 型 }\end{array}$ & $\begin{array}{l}\text { 型 } \\
\text { 型 }\end{array}$ & $\begin{array}{l}\text { 四 } \\
\text { 型 }\end{array}$ & $\begin{array}{l}\text { 高斜得 } \\
\text { 意型 }\end{array}$ & $\operatorname{lip}^{5}$ & $\begin{array}{l}\text { 高急 } \\
\text { 音賞 }\end{array}$ & (F) \\
\hline 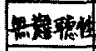 & 3 & 3 & 3 & 1 & 2 & 1 & 4 & 17 \\
\hline 伝音性 & 4 & 10 & 0 & 0 & 0 & 0 & 1 & 15 \\
\hline 虽合性 & 5 & 10 & 3 & 0 & 4 & 0 & 2 & 24 \\
\hline 或音性 & 12 & 13 & 10 & 3 & 15 & 12 & 29 & 84 \\
\hline 淟星 & 2 & 6 & 2 & 0 & 7 & 5 & 8 & 30 \\
\hline 溇梏 & 0 & 0 & 5 & 0 & 3 & 3 & 6 & 17 \\
\hline 計 & 24 & 36 & 16 & 4 & 21 & 13 & 36 & 150 \\
\hline
\end{tabular}

各型の百分率を图示した（第 2 表，第 4 (図).

耳鳴全体に就て勧察すると第3 型（高 音下降型) が最も多く 57 耳 $38.0 \%$ を古 め，第1型（水平型）８53耳 $35.4 \%$ C 多人，第5型(不定型) (18 耳, 12\%)， 第2 型（高音上昇型）(14耳, 9.3\%)， 第 4 型 (四型) (8耳, $5.3 \%$ )は少か 起.

無難德性耳鳴 17 耳では第 2 翟（高音 上型型) 6 耳 $(42.9 \%)$ ，第1 型(水平型) 5 耳 $(29.4 \%)$ ，第 3 型(商音下降型), 第 4 型（叫型）の順で第 5 型 (不定型) はなかつた，伝音性耳鳴 15 耳では第1 型（水平型）が7 耳 (46.7\%) で趣も多 $<$ ，以下第 5 型 (不定刑)，第 2 型（高 音上鼎型) 及び第 3 型(离音下降型) の 順で少く，第4型（四型）はなかつた。 感音性耳鳴 94 耳では第 3 型 (葛音下降 椞) 40 耳 $(42.5 \%)$ ，第 1 型 (水平然) 34 耳 $(36.2 \%)$ が多く，第2型（高音上昇 型)，第 4 型（四型），第 5 型(不定型) は夫タ $10 \%$ 以下であつた。

第 1 型（水平型），第5 型(不定型)て

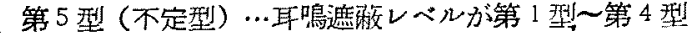
の如き䁌瞭な型を呈せす不規則であるもの.

これらの各型の典型的な例は第3図《示した。著者の 観察した 150 耳に就て各型の分布を示し，又各耳鳴短に 第4图互熄遮酸レベルから見な tinnitus audiogram

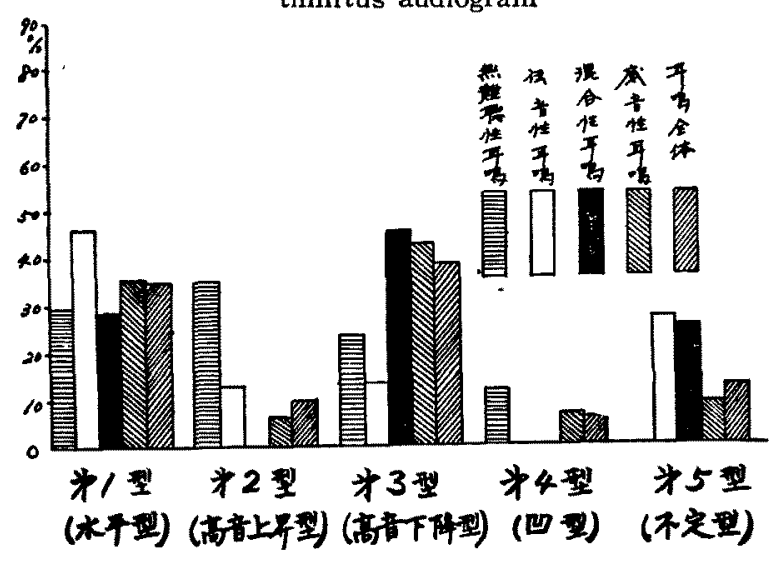

型) は后遂路性耳鳴4耳を含んだ感音性耳鳴6耳と無難 䁩性耳鳴の 2 耳のみであつた。

第 2 型 (高音上界型) 及び第 4 型 (型) 等無難聴性 耳鳴よりむ后迷路性耳踪方多かつた。 
第 5 図耳览遮獭曲線の型

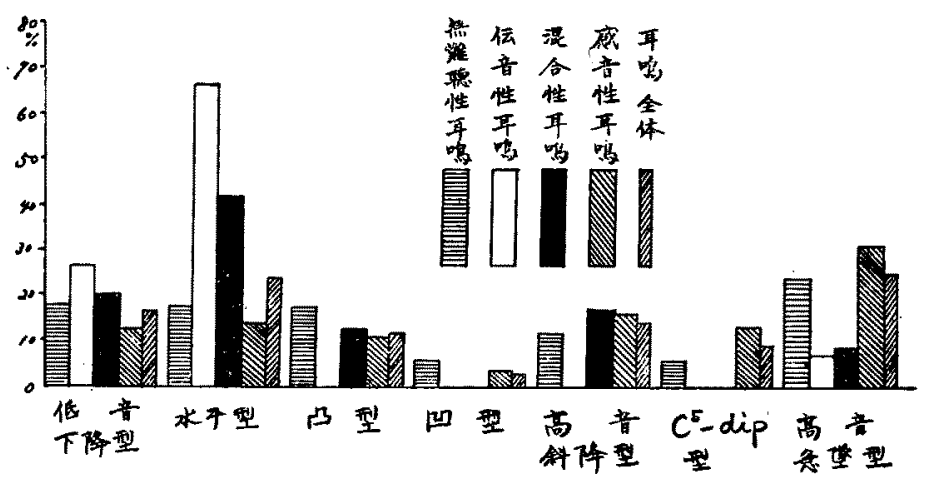

第6図耳吗遮蔽曲線の刑
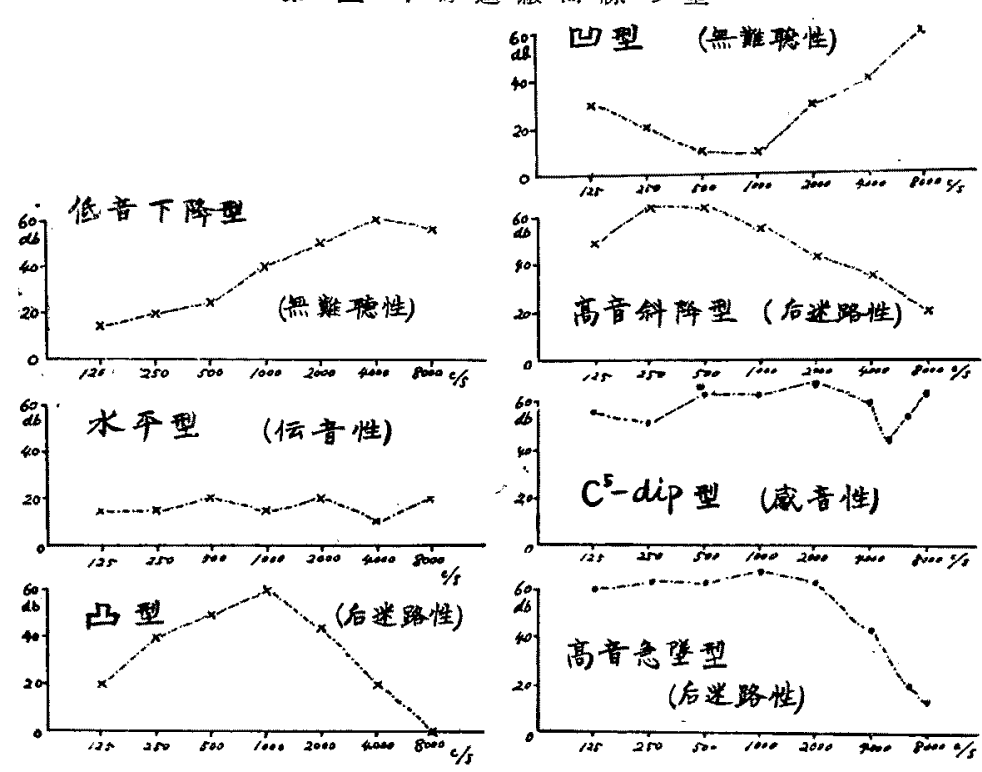

III) 耳鴽遮蔽曲線の型

気尊曲線がその経過に従つて水平型, 高音急栵型等に 分類されているのに從つて，耳鳴遮蔽曲線の型をきめ

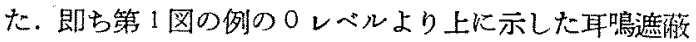
曲線をその経過に従つて低音下降型，水平算，几型，山

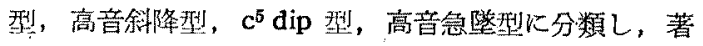
著つ権察した 150耳の耳鸣遮蔽曲腺の型を判定した（第

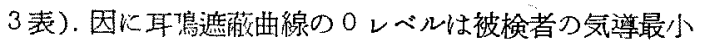
可聴閾值曲線である. 又各耳鳴海に各型の百分率を求め た（筝 5 図），各型の代表例は第6 図に示した。

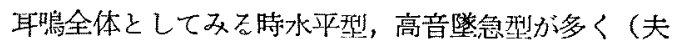
\& 36 耳，24\%)，以下低音下降型，高音斜降型 $14 \%$,
凸型 $(10.7 \%), \mathrm{c}^{5}$ dip 型 $8.7 \%$, 凹型 $2.6 \%$ 順で減少した。

無難㯖性耳鳴はいすれの型にす見 られたが高音急陮型に最子多から た. 文無難聴性耳鳴の各型の分布は 前項の場合と異つて，伝音性耳嬩の それよりる寜ろ感音性耳鸩の分布に 似ている成綪が諗められた。伭音性 耳鳴では水平型が $66.7 \%$ 示し， 他には低音下降型，高音急䉯型に見 られたのみで, 凸型, 凹型, 高音斜 降型， $c^{5}$ dip 型にはみられなかつ た。感音性耳鳴はいずれの型にも义 られたが，高音急障型に最も多く 36 耳, 24\%であつた。

水平型には伝音性耳嗎が極めて多 かつた，低音下降型にはいずれつ型 の耳鳴も見られたが伀音性耳鳴がや や多かつた. 凸型，山型，高音斜降 型， $c^{5}$ dip 型には伀音性单鳴は見ら れず，無難聴性耳鳴，感音性耳鳴が 多かつた.
N) 耳鳴遮酸レベルと気導曲 楾との関係から見た tinnitus audiogram

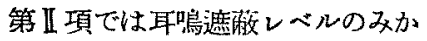
ら, 即ち耳鳴遮蔽レぶルと正常耳最 小可聴闇値との関係から観察した が，本項では耳鳴遮敉レベルと気導 曲線との関係から観察を試みた。即 ら第7図に示したような分類を行つ た。

$a$ 型 (平行型) …聑鳥遮蔽レベルと気導曲線が平行す る型.

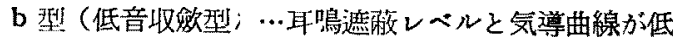
意で接近する型。

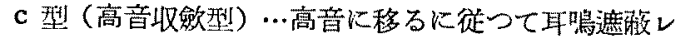
ベルと気道曲線とが徐々に接近する型。

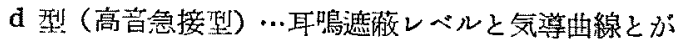
高音で急激に接近する型.

$\mathrm{e}$ 型（中音近接型）…中音域附近の周波数で最も遮敞

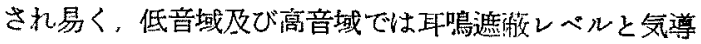
曲線とが離れる型。 


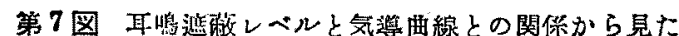
tinnitus audiogram
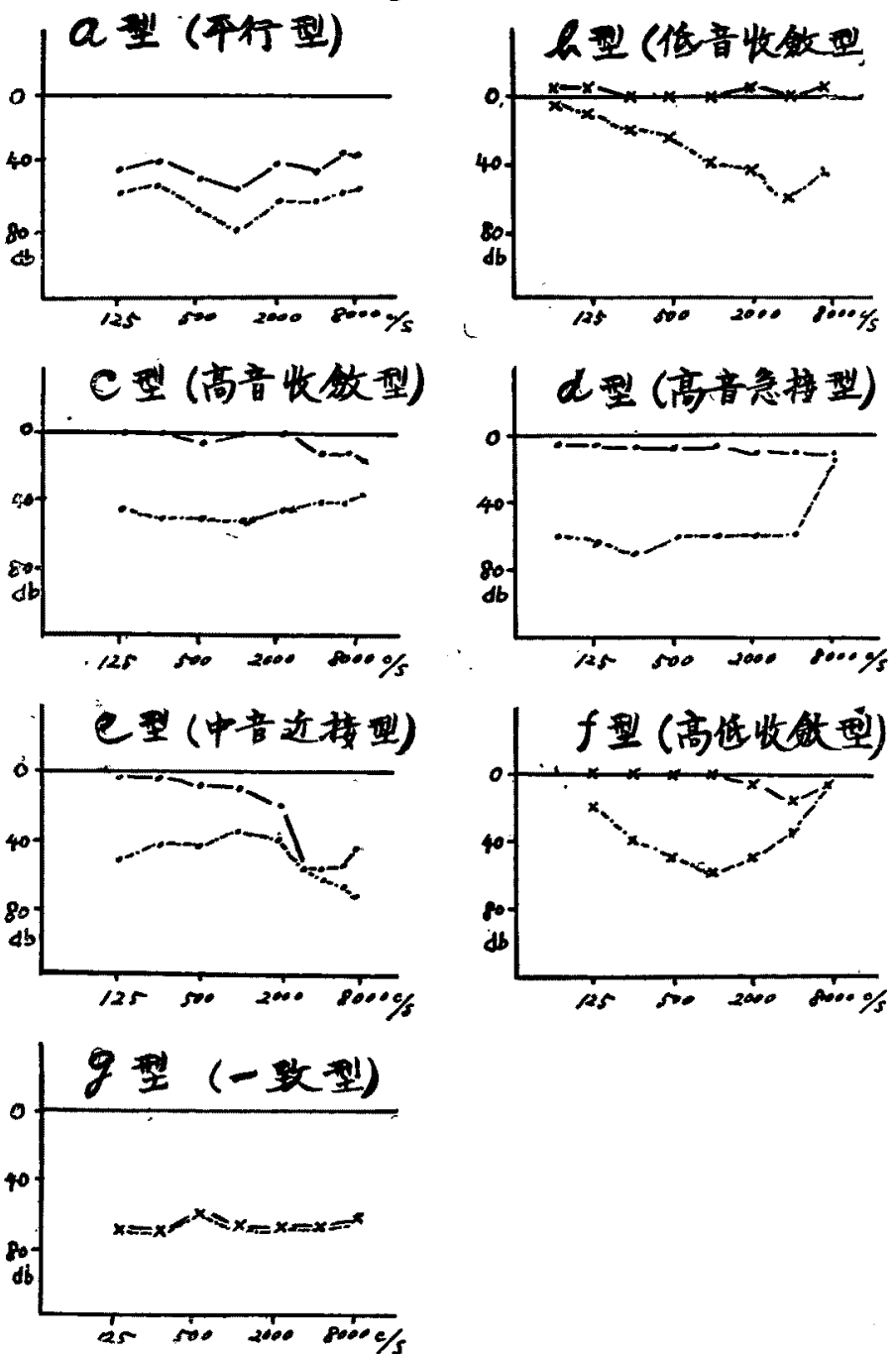

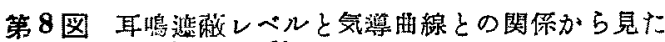
tinnitus audiogram

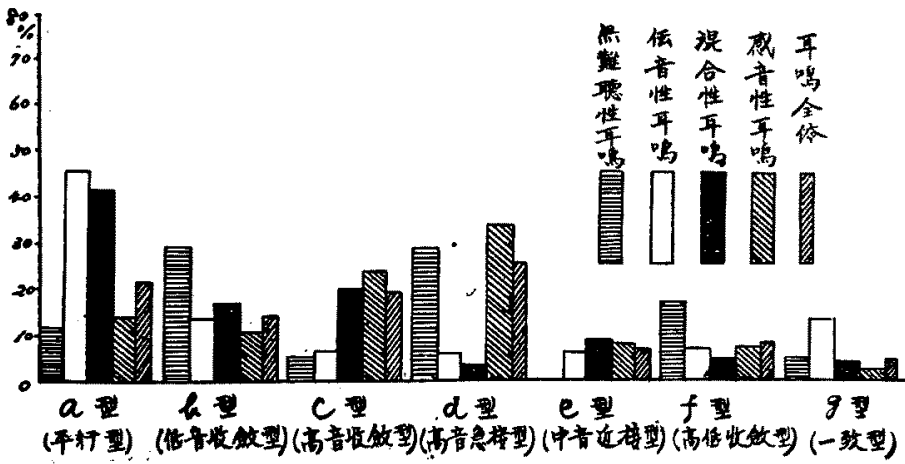

$10-103$

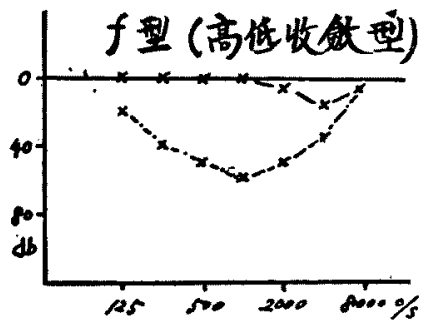

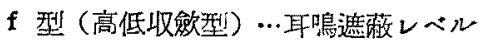
と気尊曲線が低音域及び高音域て最も接 近し，中音域で離れる型.

g 型 (一致型) …耳鳴遮蔽レベルと気 導曲線とが一致する型. 即ら純音が聴党 始めると同時に耳鳴が遮蔽されて聴えな くなる例。

著者の観察した 150 耳の耳鳴遮蔽レべ ルをこの基淮に従つて分類し，又各耳漹 毎に各型の百分率を図示した（第 4 表， 第 8 図).

耳鳴全体としてみるときd型（高音急 接型) 39 耳 $(26 \%)$ ， a型 (平行型) 32 耳 $(21.3 \%$ )，c型 (高意収歛型) 30 耳 (20\%) が多く，以下 b 型(低音収歛型)， $\mathbf{f}$ 型 (高低收歛型)，e型 (中音近接型) $\mathrm{g}$ 型 (一致型) の順に減少した。

無難聴性耳鳴はいずれの型にる見られ たが， $\mathrm{d}$ 型 (高音急接型) $29.4 \% ， \mathrm{~b}$ 型 (低音收歛型) $29.4 \%$ に最多多かつた。

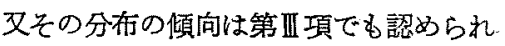
たよ5 K伝音牲耳鳴よりも感意性耳鳴の 方に似ていた。伝音性耳鳴は e 型（中音 近接型)を除いた他の型のいずれにる㒛 められたが，a型 (平行型) が7 耳 46.6. \%を占めていた，感音性耳鳴も同じくい。 すれれの型にも認められたが d 型(高音急 接型)，c型 (高音收欲型) に多加った。

$\mathbf{a}$ 型 (平行型) には伝音性耳鳴が， b 型 （低音収欱型）には無難聴性耳鳴が，c型 (高音収澰型)には感音性耳鳴が，又 d 型（高音急接型）には感音性耳鳴と無難 聴性耳鳴とが多かつたが，e型（中音近 接型)， $\mathrm{f}$ 型 (高低収斂型)， $\mathrm{g}$ 型 (一致 型)では著明な特長は認められなかつ た。

V) 耳鳴遮敕曲線とその大ささ

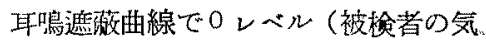
㰯曲線）に最接近している同波数とそ の距りを求めた。即ら耳鳴を最も遮蔽し 易い純音の周波数とその周波数において 遮蔽に要した純音の大きさを測定した。 本項では耳嗎遮蔽に要した純音の大ささ 
を観祭し，周波数に就ては次の 項で観察することにし た (第 5 表). 又各耳鳴毎に耳鳴遮潄に要した音の大き さの diagram を描いた（第9図）。

第4表 开暗遮蔽レベルと気莩曲線との 閂你加ら見た tinnitus audiogram

\begin{tabular}{|c|c|c|c|c|c|c|c|c|}
\hline & $a \geqslant$ & 年型 & C型 & $d$ 型 & e & $f \underline{\underline{T}}$ & g포 & +0 \\
\hline 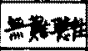 & 2 & 5 & 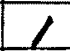 & 5 & 0 & 3 & 1 & 17 \\
\hline 昔性 & 7 & 2 & 2 & 1 & 1 & 1 & 2 & 13 \\
\hline & 10 & 4 & 5 & & $\leq$ & 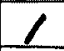 & 1 & 24 \\
\hline 音性 & $1 / 3$ & 10 & 23 & 32 & 7 & 7 & 2 & 94 \\
\hline 迷路婝 & 5 & 2 & 9 & 10 & 3 & 7 & 0 & 30 \\
\hline & 2 & 0 & 3 & 8 & 0 & 4 & 0 & 12 \\
\hline $5+\infty$ & 37 & 21 & 30 & 39 & 10 & 12 & 6 & 150 \\
\hline
\end{tabular}

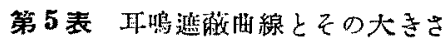

\begin{tabular}{|c|c|c|c|c|c|c|c|}
\hline 44 & 1015 & \begin{tabular}{|l|l|}
10 & 15 \\
\end{tabular} & \begin{tabular}{|l|l|}
220 & 25 \\
\end{tabular} & \begin{tabular}{|l|l|}
30 & 35 \\
\end{tabular} & $40 \mid<5$ & 5055 & ita \\
\hline & 3 & \begin{tabular}{|l|l}
2 & 3 \\
\end{tabular} & 5 & 1 & $1 / 3$ & 1 & \\
\hline & 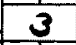 & 5 & 5 & 1 & 4 & I & 17 \\
\hline & 44 & 42 & 4 & 1 & & & \\
\hline & 8 & 6 & 4 & 1 & & & 14 \\
\hline & 44 & \begin{tabular}{|l|l|}
8 \\
\end{tabular} & 211 & & & & \\
\hline & 8 & 11 & 3 & & & & 22 \\
\hline & 2120 & $13 \mid 14$ & $14 \mid 12$ & 21 & 111 & 1 & 0 \\
\hline & 41 & 27 & 26 & 3 & 2 & 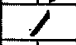 & 100 \\
\hline & 96 & 44 & 216 & & & & 37 \\
\hline & 15 & 8 & 8 & & & & 3 \\
\hline 委 & 53 & $3 / 1$ & 211 & 2 & 1 & & 10 \\
\hline & 8 & 4 & 3 & 2 & 6 & & 178 \\
\hline & 2931 & 2722 & $25 / 3$ & \begin{tabular}{l|l|}
3 & 2 \\
\end{tabular} & \begin{tabular}{l|l|}
214 \\
\end{tabular} & 11 & 60 \\
\hline & 60 & 49 & 38 & 5 & 6 & 2 & \\
\hline
\end{tabular}

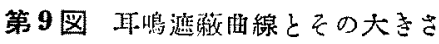

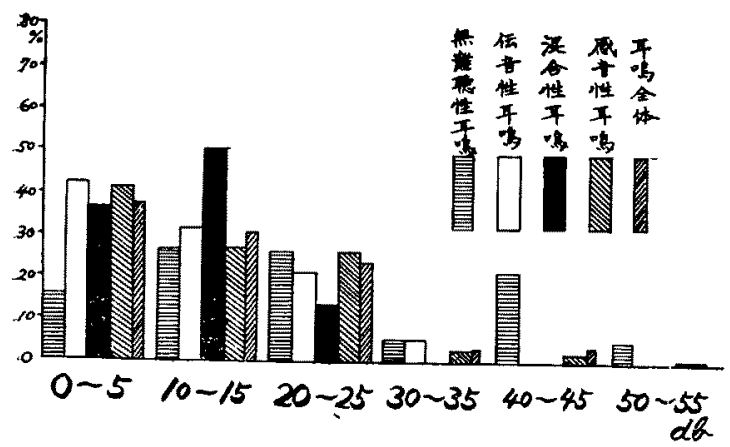

耳鴊全体汇就て見ると Odb あるいは 5db の大きさで 遮蔽されるものが 60 耳 $(37.5 \%)$ で最も多く，大きな 音で遮蔽されるもの」例は次第に減少していることが認
第 6 表 耳捣遮鹤曲線

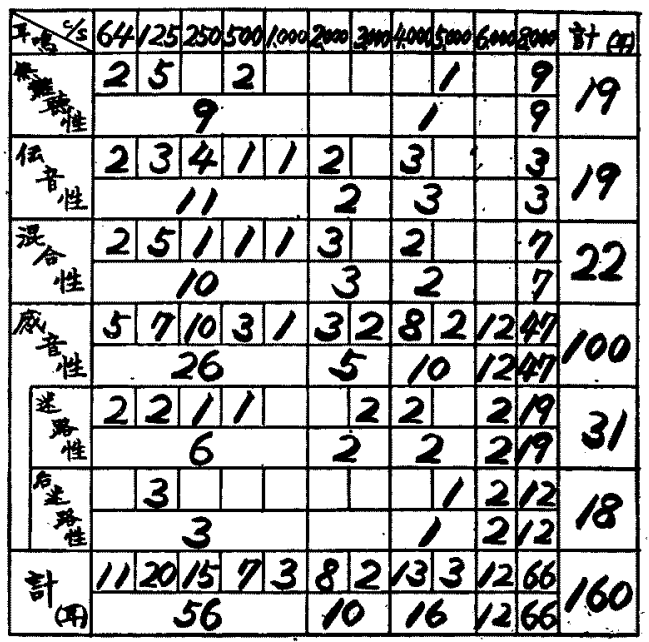

第 10 図 耳留遮蔽曲線 已周波数

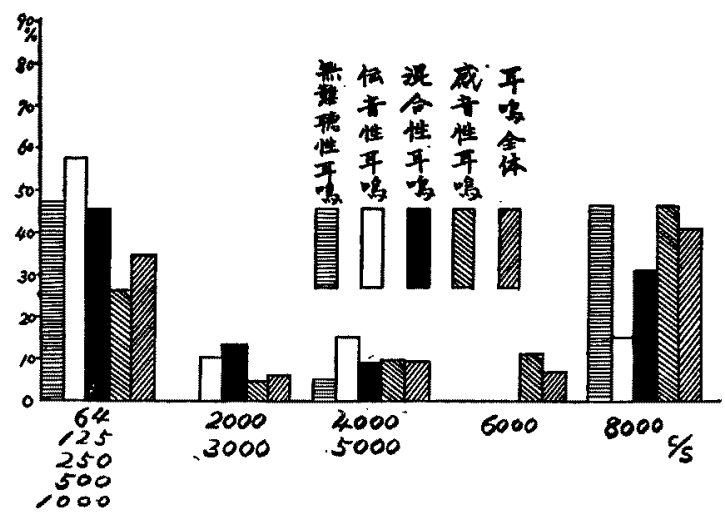

められ，91.9\%が $25 \mathrm{db}$ 以下の大いさで茞蔽されてお り，30db 以上の大きさで遮蔽されたものは13耳（8.1 \%）に過ぎなかつた. 又最大の例は $55 \mathrm{db}$ の大きさで遮 蔽された感暗性耳鳴の1例であつた。

無難聴性耳鳴の傾向は上述の耳鳴全体汇就いて見られ た傾向とや〉異つていたが，伝音性耳鳴，感音性耳鳴に 扣いては上述の耳嗎全体の観察成績と添さ似た成績を示 した.

VI) 耳鳴遮䡛曲線と周波数

耳鳴を最も遮政し易い純音の 周波数を求めた（第 6 表).

又第 6 表の成蟔を第 10 図に示す如き周波数にまとめて 観察し，各耳鴊毎にそれらの百分率を示した，

耳鳴全体としてみるとき $8000 \mathrm{c} / \mathrm{s}$ で遮蔽されるもの 
が66耳 $(41.2 \%)$ で最子多く，次で $1000 \mathrm{c} / \mathrm{s}$ 以下の低 音で遮蔽されるるのが56耳（35\%) を占め，2000〜

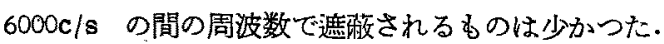
$1000 \mathrm{c} / \mathrm{s}$ 以下の低音の5ちでは $125 \mathrm{c} / \mathrm{s}$ で遮蔽されるむ のが最も多く，次には $250 \mathrm{c} / \mathrm{s}, 64 \mathrm{c} / \mathrm{s}$ の順で遮蔽され難 くなり，500c/s，1000c/s で遮蔽されるるのは $2,000 \mathrm{c} / \mathrm{s}$ で遮蔽され易いものよりも少かつた。

無薠聴性耳鳴は $8000 \mathrm{c} / \mathrm{s}$ の高音及び $1000 \mathrm{c} / \mathrm{s}$ 以下 の低音で遮蔽されるすのが最む多く，各々 9 耳 $(47.4 \%)$ を占めていた．伝音耳性鳴は低音で遮蔽され易いるのが 最る多く(11耳, $57.9 \%), 8000 \mathrm{c} / \mathrm{s}$ で遮蔽されるもの も3耳 (15.8\%) あつた。感音性耳鳴では高音で遮蔽さ れるすのが最も多く 47 耳 $(47 \%)$ を示した・但し低音 域で遮蔽され易いものも26耳（26\%)に認められた。

迷路性耳鳴，后迷路性耳鳴では特に高音域で遮潄され るものが多かつた，但し両者の間に著明な差異は認めら れなからた。

無難聴性耳鳴はその遮蔽され易い、周波数の分布から見 ると伝音性耳鳴のそれよりる寧万感音性耳鳴のそれに似 ていた.

低音域で遮蔽され易いるのは伝音性耳鳴，無難聴性耳 鳴に多く，高音域（6000 $/ \mathrm{s}, 8000 \mathrm{c} / \mathrm{s} ）$ で遮蔽され易 いものは感音性耳鳴，無難聴性耳鳴であつた.2000〜 $5000 \mathrm{c} / \mathrm{s}$ の間の周波数で遮僌され易い耳鴊の特長は見 出せなかつた.

VII) 耳鳴道蔽曲線の周波数々音色

耳鴐を最它遮蔽し易い周波数と耳鴊の音色との関係を 観察した（第7 表).

第 7 表 耳鳴の周波数 $\varepsilon$ 吾色

\begin{tabular}{|c|c|c|c|c|c|c|c|c|}
\hline 7 & & & & & & & & 㖕(更) \\
\hline $64 \sim 1000$ & 19 & 8 & 4 & 4 & 2 & 3 & 2 & 58 \\
\hline $2000-3000$ & 5 & 0 & 1 & 1 & 0 & 0 & 0 & 9 \\
\hline $4000-5,000$ & 8 & 1 & 0 & 2 & 1 & 0 & 0 & 15 \\
\hline 6000 & 5 & 5 & 10 & 0 & 1 & 10 & 0 & 15 \\
\hline 8.000 & 33 & 14 & 4 & 2 & 3 & 3 & 4 & 76 \\
\hline it (F) & 170 & 28 & 9 & 9 & 7 & 6 & 6 & 173 \\
\hline
\end{tabular}

いずれの周波数に括いても「ジーン」が最も多から た. 又「ジーン」といら音色はいずれの周波数にす関係 が認められたが，低音域よりは高音域に関係が梁いこと が明らかになつた. 又「シーン」という音色も低周波よ りは高周波に関保が深いことが認められた。この他特に
低周波，高周波に関侼が梁いという音色を見出すことは できなかつた。

\section{総括並に考按}

大和田氏等 》あるいは水落氏 ${ }^{2)}$ は両側性耳鳴患者は 除き 1 側にのみ耳鳴を訴える例に就て観察したが，著者 は耳鳴の一側性，両側性を問わずに持続性の耳鳴に就て 遮蔽曲線を求めた。両側性耳鳴患者でも充分に耳鳴遮蔽 曲線を求めることはできたし，又遮蚄曲線を描くことが できなかつた例は本篇の篗祭成績からは一庆除外した。

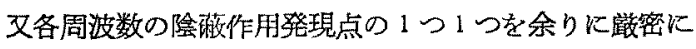
測定することは意義が軽いと考学られるから ascending method のみを用い，1つの周波数にお゙いては1〜2回 の測定を行らのみにとら゙め心。

tinnitus audiogram の表現方法としては種々の型式 が考えられるが，大和田氏りは1953年次の 2 つの型式 を発表した。即ち1つは耳鳴遮蔽曲線と聴力曲線との関 係を表わす図表であり，他は耳鳰遮蔽レぶく正常者最 小可聴音との関例である．著者が tinnitus audiogram の作り方の第 1 項及第 2 項で述べた型はなるべく大和田 氏等の方法に做つて行つたものである・な擆著は混乱 を避ける意味で, 被検者の気導曲線を○レデルの基準に とつた場合には耳鳴遮蔽曲線といら語を用い，正常耳の 最小可聴䦪值を○レデルに採用した際には耳鳴遮蔽レへ ルとした.

大和田氏等 ${ }^{1)}$ は tinnitus audiogram を耳鳴遮蔽曲 線と気導曲線との関係から 4 型に分けて観察したが，I 型の平行型（著者の I 型の水平型及びII 型の平行型に相 当す) が最む多く約 $56 \%$ で，N型（著者の V型の低音 収敛型及び可型の不定型に相当す）がこれに次き $22 \%$ であつたと報告した。著者の例では大和田氏のＩ型に相 当するI型（水平型）及び 型 (平行型) が54\%と最 す多く，又大和田氏の $\mathbf{N}$ 型に相当する $V$ 型（低音収斂 型）及びV型（不定型）が $22.6 \%$ これに次ぎ，大和 田氏等の成績と殆んど同一の結果を得た。

大和田氏等は更に各診断名々型との関係を観察し，例 数の少、関係るあるが特別の関倸は見出し難からたと報 告した．著者は各診断名とではなく聴力像を基集にして 分類した耳鳴の種類との関保を観察した結果，I型（水 平型) は伝音性耳鳴に, 林型 (平行型) は感音性耳鳴に, III型（高音収歛型）は無難聴性耳鳴に，N型（高音分離 型）は感音性耳鳴に， V型（低音収歛型）は無難聴性耳 鳴及び伝音性耳鳴に，VI型（不定型）は感音性耳鳴に関 倸が深いことが明らかであつた。 
耳鳴遮蔽レベルの型から稘察した大和田氏等 では第1 型刀水平型が最も多く 21 例 $(40 \%)$ ，第 5 型の 不定型が 10 例，20\%でこれに次ぎ，最少は第 4 型の凹 型の3例 $(6 \%$ )であつた，著者の例では第3型（高音

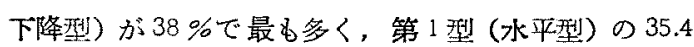
\%がこれに次ぎ，第 5 型 (不定型) $12 \%$ の順で，最少 はやはり第 4 型（型）の5.3\%であつた，大和田氏等 は第1型 (水平型) は nonvibratory tinnitus k相当 し，第2 型の高音上昇型は vibratory tinnitus 火相当 するのではいかと考え，第2 型を示す耳鳴は内耳性難 聴になく中耳性疾患に多し傾向があると述べた。著者の 例によれば第 1 型（水平型）はいずれの型の耳鳴にも見 られ，伝音性耳鳴がや〉多い傾向がみられたのみで，第 2 型 (高音上型型) は感音性耳鳴には稀で伝音性耳䳡に も少く無難聴性耳鸣に多いとい5成績が得られた。

tinnitus audiogram の作り方として上述の2つの方 法の他著者は耳鳴遮蔽曲線の型むるいは耳鳴遮蔽レヘル

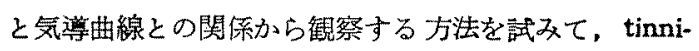
tus audiogram としてはいかなる表現型式が最も便宣 でするかを検討してみた。

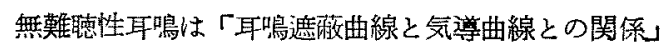
を現わしたグラフに最むよく特長が表われ，特に III 型 （高音収钦型）に著明であつた，伝音性 耳鳴の特長は 「耳鳰遮薇曲線の型」よりみた tinnitus auđiogram に 最もよく現れ，水平型に最多多く，凸型，凹型，高音利 降型， $\mathbf{c}^{5}$ dip 型の 4 型にはみられなかつた，又「耳鵈 尷薇曲線と聴力曲線との関係」を現したグラフではI型 （水平型）に多かつた・感音性耳鳴も「耳鳴遮潄曲線と 聴力曲綄之の関係」を現したグラフに最电特長的な傾向 が見られた。即ちII型 (平行翌)，N型（高音分離型)。 は感音性平鳴と関係が梁く，I型 (水平型)，吕 型 (高 音収歛型）とは密接な関係性認められなかつた。

從つて tinnitus audiogram より耳鳴の種類を判定し

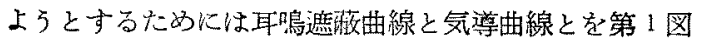
の如くに表現する万法ゔ最も適した方法ではないかと考 えられた。

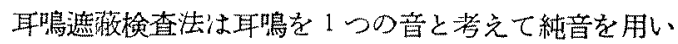

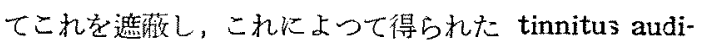
ogram より耳鳴つ周波数，大きさ，性質等を测定しよ うとする方法であり，陰政とは本法で恃耳鳴が他の純音 によつてきつとれなくなることを示するのとする，耳鳥 が被㓌藏音ですり，純音が㩊蔽音である。陰蔽作用の一 般的な特長は Mayer ${ }^{4}$ あるいは Wegel 及び Lane
等によつて研究された。これによれば除蔽音より被陰蔽 音が低い音の場合には陰蔽作用は殆んど見られないが， 被陰蔽音が除蔽音より高い音の場合には陰䔩作用は著明 である・但し後者の場合でも両者の周波数が著しくがけ

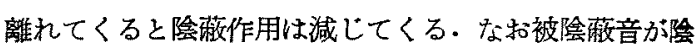
蔽音より低い音の場合でる周波数が近ければ陰蔽作用は 現われ易くなるといわれる・この原則を耳鳴遮蔽检查法 に就て適用すると耳鳴の周波数が検查純音より低い場合 には耳鳴は遮酸され難く，耳鳴の周波数が検查純音の高 さに接近するに良い漸次遮蔽され易くなり，耳鳴の周波 数が検查純音のそれより高くなると急激に遮爾され易く なり，両者の差が漸次大となるに传い再び遮蔽され難く なるということである・换言すれば耳鳴の周波数は最す 遮籍され易い純音の周波数に近似していることを意味す 万.

耳鳴の周波数は純音よりは寧万複雑な周波数特栍を有 することが考えられているので，河村氏 6)る述べてい る如く masking 法によつては耳鳴の周波数の類似音域 を涣定し得るに過ざない. 文 audiometer より発せられ る純音子低音域ではその周波数の間隔が㹧いが，高音域 では周波数間隔が広すざるし，又 audiometer の出力 の不足のために遮蔽不能な周波数るでっきて，笮密な急 味での耳鳴の周波数は測定できないが, 類似音域の決定 でも重要な資料となる。

上述の意味において耳鳴の周波数を観察した結果, 耳 呀の周波数は低音あるいは高音域にある場合が多く，中

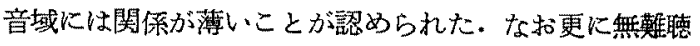
性耳鳴の周波数は低音域，蒿羔域のいずれにむ含まれて いるが，伝音性耳鳴の周波数は低音域にある場合が多 く，感音性耳鸣の周波数は高音域にあることが多いこと が明らかにされた。

次に耳鳴と音色との関係を観察した.「ジーン」「ドー ン」共に低音域よりは高音域に関係が梁いことが怹めら れ，著者うがさきに観察した成績を更に裹付けること ができた。

耳鳴遮蔽による方法によつて得られた值が耳鳴の真 の大ささを表すおのか否かに就てはな机馀討を要する

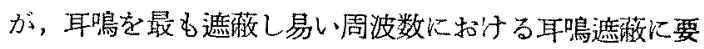
する純音の大きさを以て耳鳴の题の大きさに比例する值 と見做すことは一応適当な敏察方法であろ

Fowler ${ }^{8)}$ は耳鳴が容易に遮蔽されるのは vibratory tinnitus だけで cochlear origin であり，遮䔩され難 いかあるいは少しも遮蔽されなければ聴神経か中枢の障 
碍であり，その耳鳴は central origin であるとした。 桑森本氏等 92は后迷路性耳鳴は所謂神経性耳鴊に比し て外来音によつて遮蔽し奞いようであると述へた。遮蔽 し易いあるいは遮蔽し難いつ判定方法が異るのかも知れ ないが，著者の例では上述の如き著明な成績は認められ なかつた。

最後に無難聴性耳鳴に就て考察する．今，無難聴性耳 鳴を正常耳に見られる無響音耳鳴との異同は一応考慮外 に扎さ病的な耳鳴として取技うことにして，これが伀音 性耳鳴に関係が梁いか，あるいは感音性耳鳴の前駆症状 を示すものであるかを説明し得る成績を探求してみた。 即ち tinnitus audiogram より無難聴性耳鳴の性質を見 ると，「耳鸣遮蔽曲線と気尊曲線との関係」からは無難 聴性耳鳴は感音性耳鳴より6伝音性耳鳴に関係を持つて いるかに見え，「耳鳴遮蔽レベルの型，耳鳴遮蔽レベル

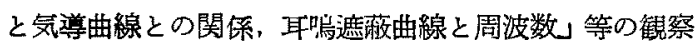
成績よりは感音性耳鳴に閏係が漈いことが推測された。 文耳鹮遮霜レベルからみた tinnitus audiogram の第 2

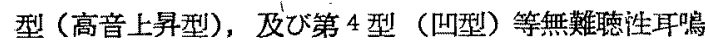
の最も多い型では迷路性耳鳴よりは后迷路性耳鳴が多か つた。従つて無難聴性耳鳴は伝音性耳鳴的な性格る持つ てはいるが，全体的にみると掌万感音性耳鳴に関連性が 大きく，感音性耳鳴のうちでも特に后迷路性耳鳴に密な 関係を持つている。

\section{結語}

耳鳴を純音を以て遮蔽し耳鳴遮蔽レベル（正常耳の最 、小可恥閶值を○レベルとす），取嗎遮蔽曲線（被检者の 最小可聴闒值を○レびルとす）を得，これらの tinnitus audiogram に就て種々の観点より観察し次の如き知見 を得た。

1) tinnitus audiogram の表覞型式としては気導曲 線と耳鳴遮蔽曲線との関保を表現する方式が各耳鳴の特 長を最むよく現しているものと思われた。即らＩ型（平
行水平型）は盾音性耳鸣に，杰型（平行高音下降型）は 感音性耳鳴に，林型（高音収歛型）は無難聴性耳鳴に， $\mathrm{N}$ 型（高音分離型）は感音性耳鳴に，V型（低音収歛 型）は無難聴性耳鳴及び伝音性耳鳴に、V型（不定型） は感音性耳鳴に関係が深かっつた。

2）耳鳴遮蔽曲綜が水平型を示す場合には盾音性耳鸣 が多かつた。

3）耳鳴の周波数は低音及び高音に関係が梁く，中音 域にあることは少かつた，更に無難聴性耳鳴の周波数は 低音域; 高羔域のいずれにもあるが，伝音性耳鳴の周波 数は低音域に感音性耳嗚の周波数は高音域にある場合が 多かつた。

4) 耳鳴の音色「ジーン」,「シーン」は低周波よりる 高周波に関保が梁かつた。

5)、無難聴性耳鳴は伝音性耳鳴よりる感音性耳鳴に特 に后迷路性耳鳴に関係が樑いと推湘された。

$$
\text { 交献 }
$$

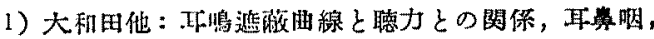

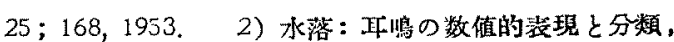

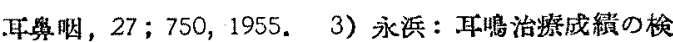

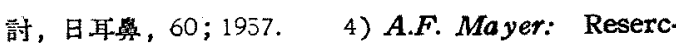
hes in acoustics Phil, Mag. 2; 1876. 5) R.L. Wegel and C.E. Lane: The auditory masking of one pure tone by anothor and its probable relation to the dynamics of inner ear Phys. Rev. 23 ；1924.6）河机：外因（頭部外傷及び晋整外

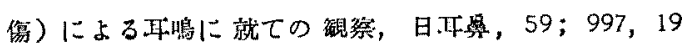

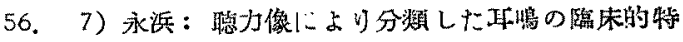
長について，日开尃，60；1957. 8) Fowler: Tinnitus aurium in the light of recent research Ann.

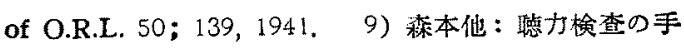
引，医学畫院，125, 1956.

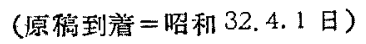

